\title{
Article \\ Synthesis of Optically Active Bicyclic Derivatives of Nitroimidazoles
}

\author{
Justyna Żwawiak *(D) and Lucjusz Zaprutko (D)
}

Citation: Żwawiak, J.; Zaprutko, L. Synthesis of Optically Active Bicyclic Derivatives of Nitroimidazoles. Compounds 2021, 1, 145-153. https://doi.org/10.3390/ compounds1030013

Academic Editor: Manuela Oliverio

Received: 16 September 2021

Accepted: 23 November 2021

Published: 2 December 2021

Publisher's Note: MDPI stays neutral with regard to jurisdictional claims in published maps and institutional affiliations.

Copyright: (c) 2021 by the authors. Licensee MDPI, Basel, Switzerland. This article is an open access article distributed under the terms and conditions of the Creative Commons Attribution (CC BY) license (https:/ / creativecommons.org/licenses/by/ $4.0 /)$.
Department of Organic Chemistry, Pharmaceutical Faculty, Poznan University of Medical Sciences, Grunwaldzka 6, 60-780 Poznan, Poland; zaprutko@ump.edu.pl

* Correspondence: jzwawiak@ump.edu.pl; Tel.: +48-618-546-678

\begin{abstract}
Nitroimidazoles are characterized by a wide range of biological activity and many of them are used as therapeutics. Moreover, some bicyclic nitroimidazooxazoles show considerable potency against Mycobacterium tuberculosis. Some authors noticed that in the case of chiral derivatives of nitroimidazodihydrooxazoles, the $(R)$ form shows a greater tuberculostatic activity than the $(S)$ enantiomer. This work describes the procurement of new 12 enantiomeric bicyclic derivatives of nitroimidazole.
\end{abstract}

Keywords: nitroimidazoles; nitroimidazodihydrooxazoles; nitroimidazotetrahydropyrimidines; optical activity

\section{Introduction}

Nitroimidazoles constitute a group of compounds with a wide range of commercial and pharmacological applications [1-3]. The antibiotic azomycin was the first pharmacologically important nitroimidazole to be invented [4]. Its discovery prompted the major impulse towards the systematic search for new drugs with anti-anaerobic protozoa activity. This investigation led to the obtaining of the 5-nitroimidazole derivative-metronidazole, which is extensively used especially in the treatment of anaerobic protozoan parasitic infections caused by Trichomonas vaginalis, Giardia duodenalis, and Entamoeba histolytica [1,5]. Moreover, metronidazole is also effective against Bacteroides, Fusobacterium, Megasphaera, Clostridium, sometimes Peptococcus and Helicobacter. Another 5-nitroimidazole derivative named Tinidazole was found to be active against Gardnella, Propionibacterium, Eubacterium, Campylobacter, Actinomyces and Spirochetes. In addition, some bicyclic nitroimidazooxazoles display considerable activity against tuberculosis [6-8]. Initially, they were investigated as radiosensitizers for use in cancer chemotherapy [9]. Systems containing the imidazo[2,1-b][1,3] oxazine ring have been found to be active against tuberculosis as well. The most promising compound of this series, PA-824 (Pretomanid), has an MIC of $0.06 \mu \mathrm{g} / \mathrm{mL}$ against $M$. bovis BCG and high activity against Mtb H37Rv [10-12]. It is used mainly for the treatment of pulmonary extensively drug resistant (XDR) and nonresponsive multidrug resistant tuberculosis.

Generally, it was found that imidazoles with a nitro group at position 5 are usually more active than the corresponding 4-nitro-derivatives. However, 4-nitroimidazoles display less toxicity than 5-nitroanalogues. These dependences are significantly observed especially for 2,4 and 2,5-dinitroimidazoles [13]. Interestingly, 2-nitroimidazole derivatives are generally more potent as radiosensitizers than the corresponding 5-nitroderivatives [14]. Introduction of an electron accepting group at position 5 in the 4-nitroimidazole ring causes an increase in cytotoxic and radiosensibilitising activity [14,15]. Nitroimidazoles are vital, particularly in the therapy of disorders caused by fungi, bacteria and protozoa [16].

The aim of this work was to obtain enantiomeric bicyclic derivatives of nitroimidazole. It is known from the chemical literature [17] that two-ring optically active compounds, which are derivatives of imidazole, can be used during asymmetric synthesis 
as chiral catalysts. It is also possible that the obtained substances will have interesting biological properties.

\section{Materials and Methods}

The melting points of the resulting series of compounds were measured in open capillaries with a Kofler apparatus and are reported without correction for the measurement conditions. Proton $\left({ }^{1} \mathrm{H}\right.$ NMR) and carbon $\left({ }^{13} \mathrm{C}\right.$ NMR) magnetic resonance spectra were performed in DMSO- $\mathrm{d}_{6}$. A Varian Gemini 300VT spectrometer (Varian, Palo Alto, Santa Clara County, CA, USA) with tetramethylsilane (TMS) as an internal standard was used to record the spectra. The chemical shift values $(\delta)$ are expressed with an accuracy of $\pm 0.01 \mathrm{ppm}$. Coupling constants are expressed in Hz. Mass spectrometry was recorded on an ADM 402 apparatus. Thin layer chromatography (TLC) was performed on aluminum plates covered with Kieselgel 60 DC-Alufol silica gel from MERCK (Darmstadt, Germany). This is a bottom-up technique using the development phase which was 9:1 $\left(\mathrm{CH}_{2} \mathrm{Cl}_{2}: \mathrm{CH}_{3} \mathrm{OH}\right)$ by volume mixture. The position of the spots of the synthesized products on the chromatograms was determined by observing the plates under UV light with a wavelength $\lambda=254 \mathrm{~nm}$. Preparative column chromatography (CC) was performed by gravity using a $30 \mathrm{~cm}$ long, 1.5 to $2.0 \mathrm{~cm}$ internal diameter chromatography column packed with 70-230 Mesh silica gel from the MERCK company. Specific rotation was measured with a Perkin Elmer 243 B polarimeter (Perkin Elmer, Waltham, MA, USA) at $20^{\circ} \mathrm{C}$.

\section{Results}

In the last few decades, there has been a significant development of asymmetric synthesis methods. This is due to the confirmation that two enantiomers of a compound can exhibit various types of pharmacological activity. Sasaki et al. proved that in the case of chiral derivatives of nitroimidazodihydrooxazoles, the $(R)$ form shows a greater tuberculostatic activity than the $(S)$ enantiomer [18]. These researchers developed a method for the synthesis of a number of optically active 6-nitroimidazo[2,1-b]-2,3-dihydrooxazoles substituted in the 2-position (Figure 1).
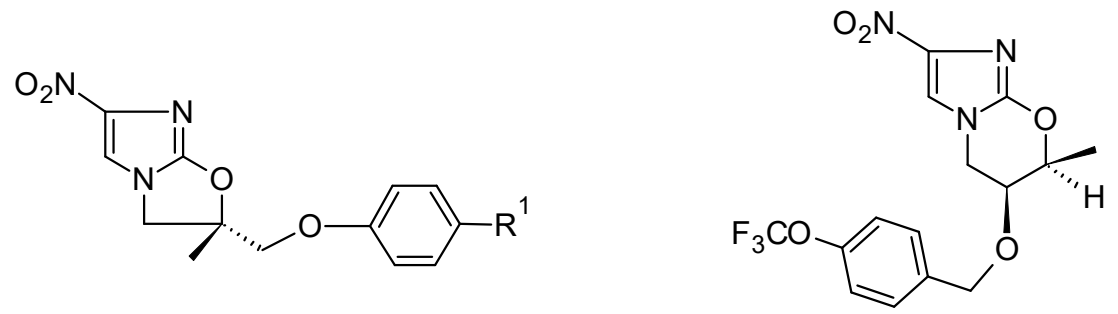

Figure 1. The structures of optically active bicyclic nitroimidazole derivatives. $\mathrm{R}^{1}=-\mathrm{H},-\mathrm{Cl},-\mathrm{CH}_{3}$, $-\mathrm{OCH}_{3},-\mathrm{CF}_{3},-\mathrm{OCF}_{3}$, cyclic secondary amines.

Enantiomerically pure epoxides are also used in the synthesis of chiral derivatives of nitroimidazotetrahydrooxazine systems, built of a 5-membered imidazole ring fused with a 6-membered cyclic oxazine system (Figure 1) [19].

It was decided to prepare an optically active 3-hydroxy-8-nitroimidazo[5,1- $b]-1,4,5,6$ tetrahydropyrimidine core in which a six-membered ring is connected to N-1 and C-5 atoms of nitroimidazole moiety. The preparation of two enantiomerically pure nitroimidazodihydrooxazoles was carried out according to the method known from the literature [20] describing the synthesis of racemic analogous compounds. For our purposes, $(R)-(+)$ - and $(S)-(-)$-epichlorohydrin was used for this reaction. In our previous works [21,22], on the basis of $X$-ray analysis results, it has been shown that the respective $(S)-(-)$-derivative was obtained when $(S)-(+)$-epichlorohydrin was used in the synthesis process and that the respective $(R)-(+)$-derivative was achieved when $(R)-(-)$-epichlorohydrin was applicated as a substrate.

In an alkaline environment, there is a reaction of intramolecular cyclization to form a bicyclic nitroimidazole derivative (Scheme 1). 
<smiles>[R]c1nc([N+](=O)[O-])c([N+](=O)[O-])[nH]1</smiles>

1: $\mathrm{R}=\mathrm{H}$ 2: $\mathrm{R}=\mathrm{CH}_{3}$

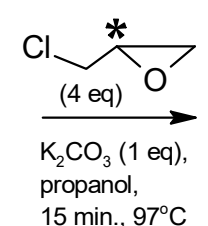<smiles>[R]c1nc([N+](=O)[O-])c2n1CC(CCl)O2</smiles>

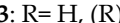

4: $\mathrm{R}=\mathrm{H},(\mathrm{S})$

5: $\mathrm{R}=\mathrm{CH}_{3}$ (R)

6: $\mathrm{R}=\mathrm{CH}_{3}(\mathrm{~S})$
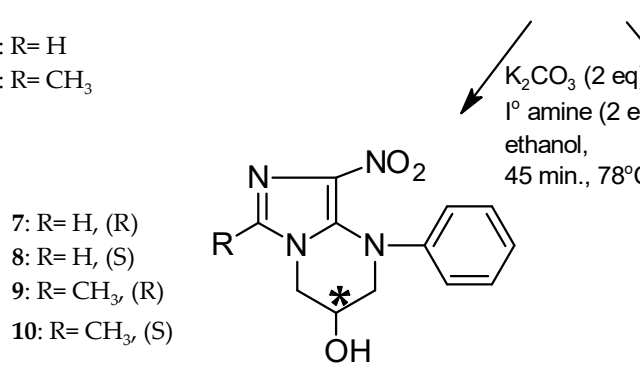

Scheme 1. The synthesis of chiral bicyclic nitroimidazole derivatives (7-14).

The substrates in a molar ratio of 1:3:0.75 (4,5-dinitroimidazole: epichlorohydrin, $\mathrm{K}_{2} \mathrm{CO}_{3}$, respectively) were heated for $25 \mathrm{~min}$ in ethanol solution. On the other hand, derivatives with a methyl group in a molar ratio of 1:2:0.5 (2-methyl-4,5-dinitroimidazole, epichlorohydrin, $\mathrm{K}_{2} \mathrm{CO}_{3}$, respectively) were heated for $15 \mathrm{~min}$ in a propanol solution. After the reaction, about $60 \mathrm{~mL}$ of water was added to the mixture each time. The solutions were extracted with methylene chloride due to there being little or no precipitate. The organic extracts were dried with anhydrous magnesium sulfate. After evaporation of the solvent, a yellow solid residue was obtained.

Then, the focus was on obtaining new enantiomeric nitroimidazotetrahydropyrimidine bicyclic systems with the use of an aromatic amine, i.e., aniline, according to the method known from the literature [23] describing the synthesis of analogous racemic compounds. These reactions were carried out on the $(R)$ - and $(S)$ - methyl derivative of the nitroimidazodihydrooxazole and the $(R)$ - and (S)-derivative devoid of the 2-methyl group (Scheme 1). The appropriate nitroimidazodihydrooxazole, aniline and $\mathrm{K}_{2} \mathrm{CO}_{3}$ were mixed in ethanol and heated under reflux conditions for $45 \mathrm{~min}$. The possible mechanism is described in [23].

In the next stage of the research, an attempt was made to synthesize analogous enantiomeric bicyclic systems with the use of an aliphatic amine, i. e., butylamine (Scheme 1). These reactions were carried out on the $(R)$ - and $(S)$-methyl derivative of nitroimidazodihydrooxazole and the $(R)$ - and $(S)$-derivative devoid of the 2-methyl group. The appropriate nitroimidazodihydrooxazole and butylamine along with the $\mathrm{K}_{2} \mathrm{CO}_{3}$ were mixed in ethanol and heated under reflux conditions for $45 \mathrm{~min}$. All synthesized compounds were subjected to spectral analysis, which confirmed their identity and structure. Detailed experimental data are presented in Appendix A Section.

The $\mathrm{m} / \mathrm{z}$ values for the molecular ions of these compounds are in agreement with the calculated molecular weights. In the ${ }^{1} \mathrm{H}$ NMR spectrum, the hydrogen atoms bound to the C-2 carbon of the imidazole ring appeared as singlets at approximately $7.6 \mathrm{ppm}(7,8)$ and $7.3 \mathrm{ppm}(\mathbf{9}, \mathbf{1 0})$. The benzene ring protons in the aniline system provided the multiplet signals which were observed in the range of 7.0-7.4 ppm. The peak was located at about $5.4 \mathrm{ppm}(\mathbf{7 , 8 , 9 , 1 0 )}$ or $5.2 \mathrm{ppm}(\mathbf{1 1}, \mathbf{1 2}, \mathbf{1 3}, \mathbf{1 4})$ and was assigned to the $-\mathrm{OH}$ group. The proton from the carbon atom bound to the hydroxyl group was visible in the form of a multiplet in the area of $4.7-4.8 \mathrm{ppm}(7,8,9,10)$, and in the case of compounds substituted with an aliphatic amine $(\mathbf{1 1}, \mathbf{1 2}, \mathbf{1 3}, \mathbf{1 4})$, these signals were shifted towards the higher magnetic field strength and were in the range of $4.4-4.5 \mathrm{ppm}$. The remaining protons from the tetrahydropyrimidine ring were observed in the ranges of 4.3-4.4 ppm and 3.9-4.1 ppm. The spectra of compounds with a methyl group in the C-2 position of the imidazole ring showed the presence of a singlet at $2.13 \mathrm{ppm}(\mathbf{1 3}, \mathbf{1 4})$ or at $2.26 \mathrm{ppm}(\mathbf{9}, \mathbf{1 0})$ derived from three $\mathrm{H}$ atoms of the methyl group. The remaining multiplets, occurring in the range of 
$0.8-4.0 \mathrm{ppm}$ in the spectra of the compounds $(\mathbf{1 1}, \mathbf{1 2}, \mathbf{1 3}, \mathbf{1 4})$, were derived from hydrogen atoms of aliphatic chains, constituting the rest of the butylamine.

In the ${ }^{13} \mathrm{C}$ NMR spectra, signals from the carbon atoms of the imidazole ring were usually found at about 146 (C-4), 134 (C-2) and 126 (C-5) ppm. The other peaks observed in the range of 122-140 ppm were assigned to the carbon atoms of the aromatic aniline ring $(7,8,9,10)$. The carbon that was bonded to the secondary hydroxyl group gave a signal at about $60 \mathrm{ppm}$, while the adjacent $C$ atoms were seen as peaks at about 55 and $44 \mathrm{ppm}$ $(\mathbf{7}, \mathbf{8}, \mathbf{9}, \mathbf{1 0})$. In the spectra of compounds with an aliphatic substituent $(\mathbf{1 1}, \mathbf{1 2}, \mathbf{1 3}, \mathbf{1 4})$, the values characterizing this group were at 69 and $44 \mathrm{ppm}$, respectively.

\section{Discussion}

Calculation of Potential Biological Activities of the Obtained Compounds Using the PASS Method and Calculation of the Partition Coefficient

The PASS program (Prediction of Activity Spectra for Substance) is widely used to assess the biological activity of substances [24]. It was developed at the Institute of Biomedical Chemistry of the Russian Academy of Sciences in the 1970s. Since then, it has been repeatedly improved and systematically updated. Access to the program is possible through the following website: www.pharmaexpert.ru/PASSOnline/ (accessed on 15 July 2021). The program predicts the occurrence of a pharmacological effect with estimated probability based on the structure of the compound in question. Using this program, we can also predict the mechanism of action, effects on fetal development (teratogenicity and embryotoxicity) and carcinogenicity. Dependencies of this kind are described on the basis of MNA (Multilevel Neighborhoods of Atoms) descriptors. The PASS program determines the potential occurrence of a specific activity $(\mathrm{Pa})$ or its absence $(\mathrm{Pi})$ for a testing compound based on the probability of its presence in the set of active and inactive substances of the SAR (Structure-Activity Relationship). This program consists of such elements as: characterization of the structure of a chemical compound, a database of known biologically active molecules and a mathematical model that is used to estimate the probability of a specific activity for the analyzed substance.

This database is updated based on information contained in various types of scientific publications. The values of $\mathrm{Pa}$ and $\mathrm{Pi}$ are in the range of $0-1$ or $0-100 \%$. A Pa result $>70 \%$ applies to compounds likely to show specific biological activity in vitro.

The Partition coefficient $(P)$ is the ratio of the concentrations of substances in two different, immiscible solvents at equilibrium [25]. Most often, one of the solvents is water, the other is a hydrophobic substance, e.g., octan-1-ol. The non-ionized form of the substance is used for measurement by selecting the appropriate $\mathrm{pH}$. The website www.vcclab.org/lab/alogps/start.html (accessed on 12 July 2021).was used to calculate the mean value of the partition coefficient. The partition coefficient is used to determine the lipophilicity of a substance. Values in the range of $\log P>1$ are considered average or good. All synthesized nitroimidazole derivatives were analyzed by the PASS C\&T method and the value of the partition coefficient was calculated for them. Table 1 shows the results of the PASS analysis as well as the mean $\log P$ value.

When testing the obtained compounds, the PASS program predicts the anti-alcohol activity of compounds 7,8 with a probability higher than $70 \%$. It must be noted, however, that most of the obtained compounds tested by the PASS method may show an effect increasing the sensitivity to radiation - the estimated radiosensitizing activity is $50-60 \%$. It must also be noted that the program did not show significant differences in predicting biological activities for the enantiomers of a given compound. The partition coefficient values of the obtained compounds are within $\log P>1$. 
Table 1. The results of PASS analysis for obtained products (7-14).

\begin{tabular}{|c|c|c|c|c|}
\hline No. & $\mathbf{P a}$ & $\mathbf{P i}$ & The Biological Activity & Average $\log P$ Value \\
\hline \multirow{3}{*}{7,8} & 0.734 & 0.005 & Alcohol dehydrogenase inhibitor & \multirow{3}{*}{1.63} \\
\hline & 0.604 & 0.014 & Radiosensitizing agent & \\
\hline & 0.591 & 0.021 & Antiviral agent & \\
\hline \multirow{2}{*}{9,10} & 0.575 & 0.005 & Antiprotozoal agent & \multirow{2}{*}{2.06} \\
\hline & 0.575 & 0.021 & Radiosensitizing agent & \\
\hline \multirow{2}{*}{11,12} & 0.673 & 0.007 & Alcohol dehydrogenase inhibitor & \multirow{2}{*}{1.40} \\
\hline & 0.591 & 0.017 & Radiosensitizing agent & \\
\hline \multirow{2}{*}{13,14} & 0.628 & 0.042 & Lowering blood pressure & \multirow{2}{*}{1.77} \\
\hline & 0.606 & 0.038 & Kidney function stimulant & \\
\hline
\end{tabular}

Author Contributions: Conceptualization, L.Z. and J.Ż.; Methodology, J.Ż.; Investigation, J.Ż.; Writing-Original Draft Preparation, J.Ż.; Writing-Review \& Editing, J.Ż. and L.Z.; Supervision, L.Z. All authors have read and agreed to the published version of the manuscript.

Funding: This research received no external funding.

Data Availability Statement: No applicable.

Conflicts of Interest: The authors declare no conflict of interest.

\section{Appendix A}

Experimental data: 4(5)-Nitroimidazole, 2-methyl-4(5)-nitroimidazole, 4,5-dinitroimidazole and 2-methyl-4,5-dinitroimidazole were obtained by the known procedures $[26,27]$.

\section{Appendix A.1. (R)- and (S)-2-Chloromethyl-7-nitroimidazo[5,1-b]-2,3-dihydrooxazole (3,4)}

$1.6 \mathrm{~g} \mathrm{(10} \mathrm{mmol)} \mathrm{of} \mathrm{4,5-dinitroimidazole} \mathrm{(1),} 2.4 \mathrm{~g}$ (30 mmol) of $(R)$ - or $(S)$-epichlorohydrin and $10 \mathrm{~mL}$ of ethanol were mixed in the $50 \mathrm{~mL}$ round-bottomed flask, followed by the addition of $1.0 \mathrm{~g}(7.5 \mathrm{mmol})$ of anhydrous $\mathrm{K}_{2} \mathrm{CO}_{3}$. The mixture was heated under reflux for $25 \mathrm{~min}$, then poured into about $60 \mathrm{~mL}$ of water and allowed to stand for several hours.

Isolation of 3: Due to the absence of precipitate, the solution was extracted repeatedly with methylene chloride. The combined organic extracts were dried with anhydrous $\mathrm{MgSO}_{4}$. Evaporation of the solvent left a yellow solid residue. The separated product was recrystallized from water with the addition of charcoal. As a result, $0.509 \mathrm{~g}$ ( $25 \%$ yield) of a cream solid was obtained with $\mathrm{mp}=151-152{ }^{\circ} \mathrm{C}, \mathrm{R}_{\mathrm{f}}=0.58$.

Isolation of 4: A crystalline solid weighing $0.762 \mathrm{~g}$ was obtained. Liquids were extracted twice with methylene chloride, then dried with $\mathrm{MgSO}_{4}$. After evaporation of the solvent, a yellow-beige precipitate was crystallized from water with the addition of activated charcoal. As a result, $0.17 \mathrm{~g}$ of pure product (4) was obtained. Both precipitates had the same $\mathrm{mp}=153-154{ }^{\circ} \mathrm{C}, \mathrm{R}_{\mathrm{f}}=0.58$, and a total weight of $0.932 \mathrm{~g}$ ( $45 \%$ yield).

\section{Appendix A.2. (R)- and (S)-2-Chloromethyl-5-methyl-7-nitroimidazo[5,1-b]-2,3-dihydrooxazole (5,6)}

$1.7 \mathrm{~g}$ (10 mmol) of 2-methyl-4,5-dinitroimidazole (2), $1.6 \mathrm{~mL}$ (20 mmol) of (R)- or (S)-epichlorohydrin and $5 \mathrm{~mL}$ of propanol were mixed in a round bottom flask, then $0.7 \mathrm{~g}$ $\left(5 \mathrm{mmol}\right.$ ) of anhydrous $\mathrm{K}_{2} \mathrm{CO}_{3}$ was added. The mixture was heated under reflux for $15 \mathrm{~min}$, then poured into about $60 \mathrm{~mL}$ of water and allowed to stand for several hours.

Isolation of 5: A small amount of precipitate was isolated, and the solution was extracted three times with methylene chloride. The combined organic extracts were dried with anhydrous $\mathrm{MgSO}_{4}$. Evaporation of the solvent gave a yellow oily residue which was purified by silica gel column chromatography using: $\mathrm{CH}_{2} \mathrm{Cl}_{2}: \mathrm{CH}_{3} \mathrm{OH}(9: 1)$ as eluent. The harvested product was crystallized from water with the addition of charcoal. A colorless precipitate of $0.19 \mathrm{~g}(8.8 \%$ yield $)$ was obtained; $\mathrm{mp}=114-116^{\circ} \mathrm{C}, \mathrm{R}_{\mathrm{f}}=0.42$.

Isolation of 6: A small amount of precipitate was isolated, and the residue was extracted three times with methylene chloride. The combined organic extracts were dried with anhydrous $\mathrm{MgSO}_{4}$. After evaporation of the solvent, a yellow oily residue was 
obtained which was purified by column chromatography. The eluent was $\mathrm{CH}_{2} \mathrm{Cl}_{2}: \mathrm{CH}_{3} \mathrm{OH}$ (98:2). As a result, $0.16 \mathrm{~g}\left(7.4 \%\right.$ yield) of colorless product (6) with $\mathrm{mp}=115-11{ }^{\circ} \mathrm{C}$, $\mathrm{R}_{\mathrm{f}}=0.42$ was obtained.

Appendix A.3. General Methods for the Synthesis of Products 7-14

0.84 mmol of appropriate $(R)$ - or (S)-2-chloromethyl-7-nitroimidazo[5,1-b]-2,3-dihydrooxazole (3-6), $1.68 \mathrm{mmol}$ of primary amine and $9 \mathrm{~mL}$ of ethanol, followed by $0.44 \mathrm{~g}(1.68 \mathrm{mmol})$ of $\mathrm{K}_{2} \mathrm{CO}_{3}$ has been mixed in a round-bottomed flask and heated under reflux conditions for $45 \mathrm{~min}$. After cooling of the reaction mixtures, the raw product was precipitated and crystallized from $75 \%$ ethanol.

Appendix A.4. (R)-1-Phenyl-3-hydroxy-8-nitroimidazo[5,1-b]-1,4,5,6-tetrahydropyrimidine (7)

As a result, $0.128 \mathrm{~g}(64 \%$ of yield $)$ of a yellow solid with $\mathrm{mp}=239-240{ }^{\circ} \mathrm{C}$ was obtained; $R_{\mathrm{f}}=0.52,[\alpha]_{\mathrm{D}}+93.7^{\circ}(\mathrm{c}=0.30, \mathrm{DMSO})$.

${ }^{1} \mathrm{H}$ NMR: $\delta 7.59$ (s, 1H, Im), 7.25-7.36 (m, 2H, Ar), 7.02-7.12 (m, 3H, Ar), $5.53(\mathrm{~s}, 1 \mathrm{H}$, $\mathrm{OH}), 4.74-4.77(\mathrm{~m}, 1 \mathrm{H}, \mathrm{C} \underline{\mathrm{H}}-\mathrm{OH}), 4.32-4.35\left(\mathrm{~m}, 2 \mathrm{H}\right.$, Pyrim. $\left.\mathrm{N}-\mathrm{CH}_{2}\right), 4.07-4.19(\mathrm{~m}, 2 \mathrm{H}$, $\operatorname{Im~} \mathrm{NCH}_{2}$ ).

${ }^{13}$ C NMR: $\delta 146.26$ (C-4 Im), 135.11 (C-2 Im), 131.79 (Ar), 128.70 (C-5 Im), 128.30 (Ar), 123, 76 (Ar), 120.63 (Ar), $60.17(\mathrm{C}-\mathrm{H}-\mathrm{OH}), 55.78\left(\mathrm{Im} \mathrm{N}^{-} \mathrm{CH}_{2}\right), 48.27$ (Pyrim. N-CH $)^{\text {) }}$

MS m/z (\%): $260.1 \mathrm{M}^{+}$(99.9).

HRMS (ES): calcd. for $\mathrm{C}_{12} \mathrm{H}_{12} \mathrm{~N}_{4} \mathrm{O}_{3}: 260.21934$, found: 260.21955 .

IR: 3400-3500 ( $\left(\right.$ O-H) ; $3200(\vee \mathrm{C}-\mathrm{H} / \mathrm{Ar} /)$; 1528, $1332\left(\vee \mathrm{C}-\mathrm{NO}_{2}\right) ; 1450-1610(\vee \mathrm{C}=\mathrm{C})$; $1260-1340(\vee \mathrm{C}-\mathrm{N})$.

Appendix A.5. (S)-1-Phenyl-3-hydroxy-8-nitroimidazo[5,1-b]-1,4,5,6-tetrahydropyrimidine (8)

As a result, $0.191 \mathrm{~g}(95 \%$ yield $)$ of a yellow solid with $\mathrm{mp}=238-240{ }^{\circ} \mathrm{C}$ was obtained; $R_{\mathrm{f}}=0.52,[\alpha]_{\mathrm{D}}-94.0^{\circ}(\mathrm{c}=0.28, \mathrm{DMSO})$.

${ }^{1} \mathrm{H}$ NMR: $\delta 7.58(\mathrm{~s}, 1 \mathrm{H}, \mathrm{Im}), 7.25-7.37(\mathrm{~m}, 2 \mathrm{H}, \mathrm{Ar}), 7.02-7.12(\mathrm{~m}, 3 \mathrm{H}, \mathrm{Ar}), 5.53(\mathrm{~s}$, $1 \mathrm{H}, \mathrm{OH}), 4.73-4.78(\mathrm{~m}, 1 \mathrm{H}, \mathrm{C} \underline{\mathrm{H}}-\mathrm{OH}), 4.32-4.35\left(\mathrm{~m}, 2 \mathrm{H}\right.$, Pyrim. $\left.\mathrm{N}-\mathrm{CH}_{2}\right), 4.06-4.20(\mathrm{~m}$, $2 \mathrm{H}, \mathrm{Im} \mathrm{N}-\mathrm{CH}_{2}$ ).

${ }^{13} \mathrm{C}$ NMR: $\delta 146.24$ (C-4 Im), 135.08 (C-2 Im), 131.72 (Ar), 128.67 (C-5 Im), 128.27 (Ar), 123, $73(\mathrm{Ar}), 120.62(\mathrm{Ar}), 60.17(\mathrm{CH}-\mathrm{OH}), 55.76\left(\mathrm{Im} \mathrm{N}-\mathrm{CH}_{2}\right), 48.25\left(\right.$ Pyrim. N-CH ${ }_{2}$ ).

MS m/z (\%): $260.1 \mathrm{M}^{+}$(99.9).

HRMS (ES): calcd. for $\mathrm{C}_{12} \mathrm{H}_{12} \mathrm{~N}_{4} \mathrm{O}_{3}: 260.21934$, found: 260.21955 .

IR: 3400-3500 ( $v$ O-H); $3200(\vee \mathrm{C}-\mathrm{H} / \mathrm{Ar} /)$; 1528, $1332\left(\vee \mathrm{C}-\mathrm{NO}_{2}\right) ; 1450-1610(\vee \mathrm{C}=\mathrm{C})$; $1260-1340(v \mathrm{C}-\mathrm{N})$.

Appendix A.6.

(R)-1-Phenyl-3-hydroxy-6-methyl-8-nitroimidazo[5,1-b]-1,4,5,6-tetrahydropyrimidine (9)

As a result, $0.110 \mathrm{~g}(52 \%$ yield $)$ of a yellow solid with $\mathrm{mp}=206-207^{\circ} \mathrm{C}$ was obtained; $\mathrm{R}_{\mathrm{f}}=0.55,[\alpha]_{\mathrm{D}}+132.7^{\circ}(\mathrm{c}=0.28, \mathrm{DMSO})$.

${ }^{1} \mathrm{H}$ NMR: $\delta$ 7.00-7.36 (m, 5H, Ar), $5.32(\mathrm{~s}, 1 \mathrm{H}, \mathrm{OH}), 4.75-4.79(\mathrm{~m}, 1 \mathrm{H}, \mathrm{C} \underline{\mathrm{H}}-\mathrm{OH})$, 4.31-4.41 (m, 2H, Pyrim. N-CH $\left.{ }_{2}\right), 4.09-4.13\left(\mathrm{~m}, 2 \mathrm{H}, \mathrm{Im} \mathrm{N}-\mathrm{CH}_{2}\right), 2.26\left(\mathrm{~s}, 3 \mathrm{H}, \mathrm{CH}_{3}\right)$;

${ }^{13} \mathrm{C}$ NMR: $\delta 146.43$ (C-4 Im), 140.33 (Ar), 136.13 (C-2 Im), 128.62 (Ar), 128.22 (C-5 $\mathrm{Im}), 124,71(\mathrm{Ar}), 122.30(\mathrm{Ar}), 61.84(\mathrm{CH}-\mathrm{OH}), 55.13\left(\mathrm{Im} \mathrm{N}-\mathrm{CH}_{2}\right), 44.16$ (Pyrim. N-CH ${ }_{2}$, $12.67\left(\mathrm{CH}_{3}\right)$.

MS m/z (\%): $274.1 \mathrm{M}^{+}$(99.9).

HRMS (ES): calcd. for $\mathrm{C}_{13} \mathrm{H}_{14} \mathrm{~N}_{4} \mathrm{O}_{3}: 274.24569$, found: 274.24578 .

IR: 3400-3500 ( $v$ O-H); $3200(\vee \mathrm{C}-\mathrm{H} / \mathrm{Ar} /)$; 1528, $1326\left(\vee \mathrm{C}-\mathrm{NO}_{2}\right) ; 1450-1610(\vee \mathrm{C}=\mathrm{C})$; $1260-1340(\vee \mathrm{C}-\mathrm{N})$. 
Appendix A.7.

(S)-1-Phenyl-3-hydroxy-6-methyl-8-nitroimidazo[5,1-b]-1,4,5,6-tetrahydropyrimidine (10)

As a result, $0.129 \mathrm{~g}(61 \%$ yield $)$ of a yellow solid with $\mathrm{mp}=204-206^{\circ} \mathrm{C}$ was obtained; $R_{\mathrm{f}}=0.55,[\alpha]_{\mathrm{D}}-131.7^{\circ}(\mathrm{c}=0.29, \mathrm{DMSO})$.

${ }^{1} \mathrm{H}$ NMR: $\delta$ 7.00-7.35 (m, 5H, Ar), $5.30(\mathrm{~s}, 1 \mathrm{H}, \mathrm{OH}), 4.74-4.80(\mathrm{~m}, 1 \mathrm{H}, \mathrm{CH}-\mathrm{OH})$, 4.29-4.40 (m, 2H, Pyrim. N-CH $), 4.08-4.13\left(\mathrm{~m}, 2 \mathrm{H}, \mathrm{Im} \mathrm{N}-\mathrm{CH}_{2}\right), 2.27\left(\mathrm{~s}, 3 \mathrm{H}, \mathrm{CH}_{3}\right)$.

${ }^{13}$ C NMR: $\delta 146.43$ (C-4 Im), $140.33(\mathrm{Ar}), 136.16$ (C-2 Im), $128.63(\mathrm{Ar}), 128.23$ (C-5 Im), 124, $71(\mathrm{Ar}), 122.27(\mathrm{Ar}), 61.85(\mathrm{CH}-\mathrm{OH}), 55.13\left(\mathrm{Im} \mathrm{N}-\mathrm{CH}_{2}\right), 44.16\left(\right.$ Pyrim. $\left.\mathrm{N}-\mathrm{CH}_{2}\right)$, $12.68\left(\mathrm{CH}_{3}\right)$.

MS m/z (\%): $274.1 \mathrm{M}^{+}(99.9)$.

HRMS (ES): calcd. for $\mathrm{C}_{13} \mathrm{H}_{14} \mathrm{~N}_{4} \mathrm{O}_{3}: 274.24569$, found: 274.24578 .

IR: 3400-3500 ( $v$ O-H); $3200(\vee \mathrm{C}-\mathrm{H} / \mathrm{Ar} /) ; 1528,1326\left(\vee \mathrm{C}-\mathrm{NO}_{2}\right) ; 1450-1610(v \mathrm{C}=\mathrm{C})$; $1260-1340(\vee \mathrm{C}-\mathrm{N})$.

Appendix A.8. (R)-1-n-Butyl-3-hydroxy-8-nitroimidazo[5,1-b]-1,4,5,6-tetrahydropyrimidine (11)

As a result, $0.119 \mathrm{~g}(57 \%$ yield $)$ of a yellow solid with $\mathrm{mp}=160-162{ }^{\circ} \mathrm{C}$ was obtained; $\mathrm{R}_{\mathrm{f}}=0.46,[\alpha]_{\mathrm{D}}+386.7^{\circ}(\mathrm{c}=0.29, \mathrm{DMSO})$.

${ }^{1} \mathrm{H}$ NMR: $\delta 7.27$ (s, 1H, Im), $5.13(\mathrm{~s}, 1 \mathrm{H}, \mathrm{OH}), 4.45-4.51(\mathrm{~m}, 1 \mathrm{H}, \mathrm{C} \underline{\mathrm{H}}-\mathrm{OH}), 4.24-4.30(\mathrm{~m}$, 2H, Pyrim. N-CH ${ }_{2}$ ), 4.03-4.12 (m, 2H, Im N-CH 2 ), 3.91-4.00 (m, 2H, N-butyl), 1.42-1.64 (m, 2H, N-butyl), 1.22-1.33 (m, 2H, N-butyl), 0.88 (t, J = 7.2 Hz, 3H, N-butyl);

${ }^{13}$ C NMR: $\delta 146.68$ (C-4 Im), 131.30 (C-2 Im), 127.72 (C-5 Im), $69.53\left(\mathrm{Im} \mathrm{N}-\mathrm{CH}_{2}\right)$, 60.44 (CH-OH), 45.31 (N-butyl), 44.35 (Pyrim. N-CH ${ }_{2}$ ), 40.12 (N-butyl), 19.17 (N-butyl), 13.69 (N-butyl).

MS m/z (\%): $240.1 \mathrm{M}^{+}(99.9)$.

HRMS (ES): calcd. for $\mathrm{C}_{10} \mathrm{H}_{16} \mathrm{~N}_{4} \mathrm{O}_{3}: 240.22924$, found: 240.22935 .

IR: 3400-3500 ( $v$ O-H); 1552, $1324(v$ C-NO 2$) ; 1020-1250$ ( $v$ C-N).

Appendix A.9. (S)-1-n-Butyl-3-hydroxy-8-nitroimidazo[5,1-b]-1,4,5,6-tetrahydropyrimidine (12)

As a result, $0.15 \mathrm{~g}(71 \%$ yield $)$ of a yellow solid with $\mathrm{mp}=154-156{ }^{\circ} \mathrm{C}$ was obtained; $\mathrm{R}_{\mathrm{f}}=0.47,[\alpha]_{\mathrm{D}}-385.7^{\circ}(\mathrm{c}=0.30, \mathrm{DMSO})$.

${ }^{1} \mathrm{H}$ NMR: $\delta 7.27$ (s, 1H, Im), $5.12(\mathrm{~s}, 1 \mathrm{H}, \mathrm{OH}), 4.45-4.51(\mathrm{~m}, 1 \mathrm{H}, \mathrm{CH}-\mathrm{OH}), 4.24-4.31(\mathrm{~m}$, 2H, Pyrim. N-CH $)_{2}, 4.03-4.11$ (m, 2H, Im N-CH $), 3.92-4.00$ (m, 2H, N-butyl), 1.42-1.64 (m, 2H, N-butyl), 1.21-1.33 (m, 2H, N-butyl), 0.88 (t, J = 7.2 Hz, 3H, N-butyl).

${ }^{13}$ C NMR: $\delta 146.66$ (C-4 Im), 131.28 (C-2 Im), 127.70 (C-5 Im), $69.54\left(\mathrm{Im} \mathrm{N}-\mathrm{CH}_{2}\right)$, 60.43 (CH-OH), 45.31 (N-butyl), 44.34 (Pyrim. N- $\mathrm{CH}_{2}$ ), 40.12 (N-butyl), 19.17 (N-butyl), 13.69 (N-butyl).

MS m/z (\%): $240.1 \mathrm{M}^{+}(92.0)$.

HRMS (ES): calcd. for $\mathrm{C}_{10} \mathrm{H}_{16} \mathrm{~N}_{4} \mathrm{O}_{3}: 240.22924$, found: 240.22934 .

IR: 3400-3500 ( $v$ O-H); 1520, $1324\left(\vee \mathrm{C}-\mathrm{NO}_{2}\right) ; 1020-1250(\vee \mathrm{C}-\mathrm{N})$.

Appendix A.10.

(R)-1-n-Butyl-3-hydroxy-6-methyl-8-nitroimidazo[5,1-b]-1,4,5,6-tetrahydropyrimidine (13)

As a result, $0.105 \mathrm{~g}(50 \%$ yield $)$ of a yellow solid with $\mathrm{mp}=151-153^{\circ} \mathrm{C}$ was obtained; $\mathrm{R}_{\mathrm{f}}=0.41,[\alpha]_{\mathrm{D}}+460.0^{\circ}(\mathrm{c}=0.16, \mathrm{DMSO})$.

${ }^{1} \mathrm{H}$ NMR: $\delta 5.18(\mathrm{~d}, \mathrm{~J}=3.4 \mathrm{~Hz}, 1 \mathrm{H}, \mathrm{OH}), 4.47-4.55(\mathrm{~m}, 1 \mathrm{H}, \mathrm{C} \underline{\mathrm{H}}-\mathrm{OH}), 4.05-4.25(\mathrm{~m}, 2 \mathrm{H}$, Pyrim. N-CH $\left.{ }_{2}\right), 3.87-3.92\left(\mathrm{~m}, 2 \mathrm{H}, \mathrm{Im} \mathrm{N}-\mathrm{CH}_{2}\right), 3.62-3.71\left(\mathrm{~m}, 2 \mathrm{H}, \mathrm{N}-\right.$ butyl), $2.13\left(\mathrm{~s}, 3 \mathrm{H}, \mathrm{CH}_{3}\right)$, 1.37-1.65 (m, 2H, N-butyl), 1.23-1.30 (m, 2H, N-butyl), 0.87 (t, J = 7.2Hz, 3H, N-butyl);

${ }^{13} \mathrm{C}$ NMR: $\delta$ 147.16 (C-4 Im), 135.94 (C-2 Im), 124.00 (C-5 Im), $69.78\left(\mathrm{Im} \mathrm{N}-\mathrm{CH}_{2}\right), 60.54$ (CH-OH), 45.29 (N-butyl), 43.50 (Pyrim. N-CH 2 ), 30.39 (N-butyl), 19.20 (N-butyl), 13.73 (N-butyl), $12.56\left(\mathrm{CH}_{3}\right.$ at $\left.\mathrm{C}-2 \mathrm{Im}\right)$.

MS m/z (\%): $254.1 \mathrm{M}^{+}(99.9)$.

HRMS (ES): calcd. for $\mathrm{C}_{11} \mathrm{H}_{18} \mathrm{~N}_{4} \mathrm{O}_{3}: 254.25559$, found: 240.25564 .

IR: 3400-3500 ( $v$ O-H); 1560, $1337\left(\vee \mathrm{C}-\mathrm{NO}_{2}\right) ; 1020-1250(\vee \mathrm{C}-\mathrm{N})$. 
Appendix A.11.

(S)-1-n-Butyl-3-hydroxy-6-methyl-8-nitroimidazo[5,1-b]-1,4,5,6-tetrahydropyrimidine (14)

As a result, $0.13 \mathrm{~g}(62 \%$ yield $)$ of a yellow solid with $\mathrm{mp}=154-155^{\circ} \mathrm{C}$ was obtained; $\mathrm{R}_{\mathrm{f}}=0.42,[\alpha]_{\mathrm{D}}-460.8^{\circ}(\mathrm{c}=0.16, \mathrm{DMSO})$.

${ }^{1} \mathrm{H}$ NMR: $\delta 5.18$ (d, J = 3,4 Hz, 1H, OH), 4.47-4.55 (m, 1H, C프-OH), 4.05-4.25 (m, 2H, Pirym. N-CH $)$, 3.87-3.92 (m, 2H, Im N-CH $), 3.62-3.71(\mathrm{~m}, 2 \mathrm{H}, \mathrm{N}-$ butyl), 2.13 (s, 3H, $\mathrm{CH}_{3}$ ), 1.37-1.65 (m, 2H, N-butyl), 1.23-1.30 (m, 2H, N-butyl), 0.87 (t, J = 7,2 Hz, 3H, butyl); ${ }^{13}$ C NMR: $\delta 147.09$ (C-4 Im), 135.83 (C-2 Im), 123.97 (C-5 Im), $69.73\left(\mathrm{Im} \mathrm{N}-\mathrm{CH}_{2}\right), 60.54$ (CH-OH), 45.26 (N-butyl), 43.47 (Pyrim. N-CH (N) $^{2} 30.34$ (N-butyl), 19.14 (N-butyl), 13.66 (N-butyl), $12.50\left(\mathrm{CH}_{3}\right.$ at $\left.\mathrm{C}-2 \mathrm{Im}\right)$.

MS m/z (\%): $254.1 \mathrm{M}^{+}(99,9)$.

HRMS (ES): calcd. for $\mathrm{C}_{11} \mathrm{H}_{18} \mathrm{~N}_{4} \mathrm{O}_{3}: 254.25559$, found: 240.25565 .

IR: 3400-3500 ( v O-H); 1560, 1337 ( $v$ C-NO 2$) ; 1020-1250$ ( $v$ C-N).

\section{References}

1. Mital, A. Synthetic Nitroimidazoles: Biological Activities and Mutagenicity Relationships. Sci. Pharm. 2009, 77, 497-520. [CrossRef]

2. Olender, D.; Żwawiak, J.; Zaprutko, L. Multidirectional Efficacy of Biologically Active Nitro Compounds Included in Medicines. Pharmaceuticals 2018, 11, 54. [CrossRef] [PubMed]

3. Żwawiak, J.; Olender, D.; Zaprutko, L. Some nitroimidazole derivatives as antibacterial and antifungal agents in in vitro study. J. Med. Sci. 2019, 88, 47-51. [CrossRef]

4. Maeda, K.; Osata, T.; Umezawa, H. A new antibiotic, azomycin. J. Antibiot. 1953, 6, 182.

5. Townson, S.M.; Boreham, P.F.L.; Upcroft, P.; Upcroft, J.A. Resistance to the nitroheterocyclic drugs. Acta Trop. 1994, 56, $173-194$. [CrossRef]

6. Clifton, E.B.; Boshoff, H.I.M.; Dowd, C.F. Prospects for clinical introduction of nitroimidazole antibiotics for the treatment of tuberculosis. Curr Pharm Design. 2004, 10, 3239-3262.

7. Adib, M.; Sheibani, E.; Mostofi, M.; Ghanbary, K.; Bijanzadeh, H.R. Efficient highly diastereoselective synthesis of 1,8a-dihydro7H-imidazo[2,1-b][1,3]oxazines. Tetrahedron 2006, 62, 3435-3438. [CrossRef]

8. Agrawal, K.C.; Bears, K.; Sehgal, R.K.; Brown, J.N.; Rist, P.E.; Rupp, W.D. Potential radiosensitizing agents. Nitroimidazoles. J. Med. Chem. 1979, 22, 583-586. [CrossRef] [PubMed]

9. Nagarajan, K.; Shankar, R.; Rajappa, S.; Shenoy, S.T.; Costa-Pereira, R. Nitroimidazoles XXI. 2,3-dihydro-6-nitroimidazo[2,1b]oxazoles with antitubercular activity. Eur. J. Med. Chem. 1989, 24, 631-633. [CrossRef]

10. Thompson, A.M.; Bonnet, M.; Lee, H.H.; Franzblau, S.G.; Wan, B.; Wong, G.S.; Cooper, C.B.; Denny, W.A. Antitubercular Nitroimidazoles Revisited: Synthesis and Activity of the Authentic 3-Nitro Isomer of Pretomanid. ACS Med. Chem. Lett. 2017, 8, 1275-1280. [CrossRef]

11. Xu, J.; Li, S.Y.; Almeida, D.V.; Tasneen, R.; Barnes-Boyle, K.; Converse, P.J.; Upton, A.M.; Mdluli, K.; Fotouhi, N.; Nuermberger, E.L. Contribution of Pretomanid to Novel Regimens Containing Bedaquiline with either Linezolid or Moxifloxacin and Pyrazinamide in Murine Models of Tuberculosis. Antimicrob Agents Chemother. 2019, 63, e00021-19. [CrossRef] [PubMed]

12. Showalter, H.D. Recent Progress in the Discovery and Development of 2-Nitroimidazooxazines and 6-Nitroimidazooxazoles to Treat Tuberculosis and Neglected Tropical Diseases. Molecules 2020, 25, 4137. [CrossRef] [PubMed]

13. Mukherjee, T.; Boshoff, H. Nitroimidazoles for the treatment of TB: Past, present and future. Future Med. Chem. 2011, 3, 1427-1454. [CrossRef]

14. Boyer, J.H. Nitroazoles; VCH Publishers Inc.: Deerfield Beach, FL, USA, 1986; pp. 165-166.

15. Wardman, P. Nitroimidazoles as hypoxic cell radiosensitizers and hypoxia probes: Misonidazole, myths and mistakes. Br. J. Radiol. 2019, 92, 20170915. [CrossRef]

16. Zhang, J.; Ba, Y.; Wang, S.; Yang, H.; Hou, X.; Xu, Z. Nitroimidazole-containing compounds and their antibacterial and antitubercular activities. Eur. J. Med. Chem. 2019, 179, 376-388. [CrossRef] [PubMed]

17. Liu, S.; Zhang, Z.; Xie, F.; Butt, N.A.; Sun, L.; Zhang, W. First catalytic enantioselective synthesis of P-stereogenic phosphoramides via kinetic resolution promoted by a chiral bicyclic imidazole nucleophilic catalyst. Tetrahedron Asymmetry 2012, 23, 329-332. [CrossRef]

18. Sasaki, H.; Haraguchi, Y.; Itotani, M.; Kuroda, H.; Hashizume, H.; Tomishige, T.; Kawasaki, M.; Matsumoto, M.; Komatsu, M.; Tsubouchi, H. Synthesis and Antituberculosis Activity of a Novel Series of Optically Active 6-Nitro-2,3-dihydroimidazo[2,1b]oxazoles. J. Med. Chem. 2006, 49, 7854-7860. [CrossRef] [PubMed]

19. Li, X.; Manjunatha, U.H.; Goodwin, M.B.; Knox, J.E.; Lipinski, C.A.; Keller, T.H.; Barry, C.E.; Dowd, C.S. Synthesis and antitubercular activity of 7-(R)- and 7-(S)-methyl-2-nitro-6-(S)-(4-(trifluoromethoxy)benzyloxy)-6,7-dihydro-5H-imidazo[2,1b][1,3]oxazines, analogues of PA-824. Bioorg. Med. Chem. Lett. 2008, 18, 2256-2262. [CrossRef] [PubMed]

20. Zaprutko, L.; Gajdziński, M.; Michalska, W.; Pietkiewicz, K.; Lutomski, K.; Łukaszewski, Z.; Wrzeciono, U. Azoles. Part 27: Nitroimidazole derivatives, their antibacterial and antifungicidal activity and electron affinity. Pharmazie 1989, 44, 81-84. 
21. Gzella, A.; Żwawiak, J.; Zaprutko, L. (R)-(+)-3-Chlor-1-(4-morpholino-5-nitro-1H-imidazol-1-yl)propan-2-ol. Acta Crystallogr. E 2005, 61, o4071-o4072. [CrossRef]

22. Gzella, A.; Żwawiak, J.; Zaprutko, L. (S)-(-)-3-Chlor-1-(4-morpholino-5-nitro-1H-imidazol-1-yl)propan-2-ol. Acta Crystallogr. E 2005, 61, o4231-o4232. [CrossRef]

23. Zaprutko, L.; Żwawiak, J.; Augustynowicz-Kopeć, E.; Zwolska, Z.; Bartoszak-Adamska, E.; Nowicki, W. Synthesis, structure and biological evaluation of novel bicyclic nitroimidazole derivatives. Arch. Pharm. Chem. Life Sci. 2012, 345, 463-467. [CrossRef] [PubMed]

24. Parasuraman, S. Prediction of activity spectra for substances. J. Pharmacol. Pharmacother. 2011, 2, 52-53. [CrossRef] [PubMed]

25. Ghose, A.K.; Viswanadah, V.V.; Wendoloski, J.J. Prediction of hydrophobic (lipophilic) properties of small organic molecules using fragmental methods: An analysis of ALOGP and CLOGP methods. J. Phys. Chem. 1998, 102, 3762-3772. [CrossRef]

26. Fargher, R.G.; Pyman, F.L. XXVI. Nitro-, arylazo-, and amino-glyoxalines. J. Chem. Soc. 1919, 115, 217-252. [CrossRef]

27. Nowikow, S.S.; Chmielnickij, L.; Lebiedew, O.W.; Sevastyanova, V.V.; Epishina, L.V. Nitration of imidazoles with various nitrating agents. Chimija Geter. Sojed. 1970, 6, 503-507. 